Dijana Cerovski

UDK: $902.01 ; 069.01$

Museology and Heritology

ID BROJ: 195914508

University of Ljubljana

dicerovski@gmail.com

Original research article

Received: July 04, 2011

Accepted: September 05, 2011

\title{
ARCHAEOLOGY THROUGH THE EYES OF MUSEOLOGY - Archaeology as a science and as heritage -
}

\begin{abstract}
By now it is clear that archaeology in the last few decades has changed enormously. The biggest change is that it is no longer limited to just research, but it has been called upon to share information and help manage non renewable sources, in other words, our heritage. These changes have, in themselves, brought new responsibilities, which are necessary for archaeology to show a balanced and trustworthy interpretation of the past, in a way that does not present the past as event, isolated from the modern world, but as a basis of modern society. What is archaeological science and what is archaeological heritage? What came first; was it archaeological science or did the concept of archaeological heritage appear earlier? And in which contexts do we use both the terms? In this paper we first present archaeology in the perspectives of science and heritage and secondly, the development of the modern museum as a medium and a source of interpretation and presentation of archaeology both inside and outside the museum. We conclude with a comparison of archaeology and museology and search for common points between the two disciplines.
\end{abstract}

\section{KEY WORDS: ARCHAEOLOGICAL HERITAGE, INTERPRETATION, PRESENTATION, MODERN} MUSEUM, MUSEOLOGY.

\section{INTRODUCTION}

Since its early beginnings, archaeology has developed into a science with its own theory and methods of work, even though some critics do not see it as a science due to its humanistic character.

However, because it is producing new knowledge about the past and contributing to knowledge regarding the function and culture of past societies, it is allowing for a better insight, lowering the level of subjectivism and raising the level of objectivity and of much needed scientificity. In Europe it is recognised as an independent discipline or science and in America it is a part of anthropology (Olsen 2002: 45). Between the terms archaeology and archaeological heritage exists a line because archaeology as a science is still very academic and is producing knowledge mostly for professional circles, whereas archaeological heritage, on the other hand, is evolving into an industry for a wide range of consumers. Nevertheless, it is exactly this interpretation of archaeological 
heritage in the museum that represents the biggest link between scientific archaeology and the public (Shanks and Tilley 1992: 68). The term heritage is used mostly by institutions that are dealing with the preservation and conservation of heritage. Academics (the processual and post processual archaeologists) talk about evidence, an artefact, context, material culture and cultural source (Carman 2002: 12 - 15). If we consider the opinions of academic archaeologists from the 90's, their attitudes towards museum presentation do not appear to be very positive. The presentations are supposed to be linear, one-sided and non democratic (Shanks and Tilley 1992, 90-91) and are mostly presentations made by museum curators.

Is this true? Further on we will present an overview of the development or changes in archaeological theory and method, for the purpose of showing the distinction between archaeological theory and discussions on heritage. We will also show the connection between the two areas, as seen in museums and suggest the common points between archaeology and museology.

\section{ARCHAEOLOGY AS A SCIENCE}

Archaeology is an empirical discipline whose primary task is to collect knowledge about the past (Olsen 2002: 21). At its foundation it has its own theory, together with systematics, subject of research and method of work. Archaeology was influenced the most by three theoretical schools, whose theory and work methods we will present: cultural historical (until 1960), processual (until 1980) and post processual.

The theory of cultural historical archaeology can be described as naive empiricism, based on an inductive work method. It means that the cognitive process is moving from the basic to the general and that it requires material proof and empirical evidence for its synthesis. For the archaeologist this requires first to conclude the excava- tions, then to classify all the information and only then, on the basis of the classified knowledge and new information, to develop conclusions (on the chronology, technology and economy). Another way of using the inductive method is to use analogies. Cultures and objects are connected with the help of mutual similarities or analogies. Cultural historical archaeology was criticised on more than one occasion due to the lack of problem orientation when collecting the material, and because of the lack of precise definitions and the lack of methods for testing the evidence and hypotheses.

Collecting, describing and systemising are supposed to be goals in themselves (Olsen 2002: 75) The period between 1900 - 1960 was named as "a big sleep" by Renfrew. Clarke has (in 1968) described historical archaeology as an intuitive skill without a clearly defined theoretical basis. Due to the lack of objectivity and clear criteria on archaeological excavations the credibility of the cultural historical discipline was based on the authority of archaeologists. The biggest discoveries were perceived as a result of the almost mythical abilities of famous discoverers and were appreciated only based on this fact. The way out, or solution, was found in the use of processual archaeology. The characteristics of this new wave were the empirical verifiability, transparency and deductive logic that were demanded for the arguments to be true; the connection between premise and conclusion. Processual archaeology wanted to give a transcultural and universal explanation of past events, the focus being on general laws on which the society functioned and changed. Cultural historical archaeology, on the other hand, wanted to reconstruct specific cultural histories. In the beginning processual archaeology wanted to reveal the general cultural laws that would explain the processes in the past. Deductive checks and universal explanations, based on laws, remained part of processual rhetoric, and were, to a limited extent, included into the real excavations. Eventually the attention focused on the laws and principles at the lower level that 
explain the archaeological structures and their connections with human behaviour (Olsen 2002: 86 - 87). A critical period for processual archaeology, between 1960 and 1980, positioned the discipline among the natural sciences and took on their methodological models, based on a hypothesis of formulations of presupposed laws and relying on the accumulative growth of scientific data, and lead to the creation of postprocessual school (Olsen 1992: 419). Its main orientation became conceptual archaeology, based on the interpretation of archaeological contexts. According to Carman (Carman 2002: 7) a state of accommodation or comfort between processualism and postprocessualism has developed. Cognitive processualism appeared, that introduced symbolics into (postprocessual) work, while interpretive archaeology tried to put emphasis on the common points between postprocessualists and processualists in the field of archaeological practice. Postprocessual archaeology draws its theory and methods from social theory, the study of symbols, semiotics and gender studies.

At the end of the 80's and at the beginning of the 90's the gap between theoretical archaeologists and the performers/practitioners of archaeology was becoming wider and wider. Questions appeared such as; who is the interpretation for and from which point of view are we interpreting etc. This movement was the means by which the commercialisation of heritage was able to get bigger and bigger. Archaeology and museums became part of the postmodern era. It became important to make the past active and to apply it to the interpretation, making it accessible to as many people as possible. The result of this was that archaeologists became aware that they had to report on their work to various sections of the public. Moving further up the ladder of protection, preservation, conservation, reconstruction and reshaping, represents a step away from the official towards the marginal and a move towards the popular, active, interpreted, living history (Hodder 1993: 16-18).

\section{ARCHAEOLOGY AS HERITAGE}

The term archaeological heritage becomes very subjective if we look at examples of the different definitions of archaeological heritage used or developed by different interest groups around the world. On the basis of research on the terminology of archaeologists, conservators and heritage managers, Carman has explained the difference between archaeological record, the object of research, and archaeological source which we call heritage and is the object of archaeological investigation meant for a narrower, scientific archaeological public. Heritage, on the other hand, is meant for future research and is presented and interpreted for a wider public. The examinations of the usage of different terms since the mid 80's shows there is no consensus on what "the archaeological record" really means. Furthermore, Patrik noticed two directions within the explanation of the term; the first direction, or model, is a physical model showing the processual approaches, the record is understood as a fossilised record. Some processual archaeologists (among them: Binford, Clarke, Schiffer) use the following words to name the object of research: record (material deposit, material remains, archaeological patterns, archaeological report), artefact, context, object of cultural deposits (Carman 2002: 13). The second model is textual or postprocessual, the record is supposed to contain the meanings. The representatives of postprocessual or interpretive archaeology (among them: Tilley, Barrett, Hodder) are dealing with material culture, cultural sources.

Archaeological heritage in a wider sense is the material link between cultures, identity, and power and presents a symbolical and cultural landscape. It is an integral part of broader cultural heritage. According to Skeates (Skeates 2000) we can define it in two ways. First as the material culture of former societies, which persisted until today, and second as a process, through which the material culture of former societies was re-evaluated 
and reused in the present time. Shanks (Shanks 1990: 302-307) describes heritage as emblematic, as an agglomeration of locations and objects with certain meanings and associations. It also presents a sensory experience of sights, smells and sounds. Walsh understands heritage as a part of postmodern culture, Shanks, on the other hand, claims heritage effects people as it gives the feeling of identity and gives meaning to the world around us. Every day life is too rational; a visit to the archaeological site gives us the feeling of uniqueness and a connection with history. Even after confronting these feelings with theory, they persist.

On the other hand, different terms are used by conservators and by those who are managing and conserving heritage, resources, and cultural resources. Heritage is often described using legal terms: cultural goods, cultural objects, cultural heritage, cultural relic, cultural treasures, and cultural goods. Interestingly, those trading with heritage talk about antiquities (Carman 2002: 12-14). In other words, heritage described in legal terms does not embrace only material heritage (monuments, sites, artefacts), but also the research tradition and the knowledge of how to survive (Trotzig 1993) i.e. convival knowledge and skills. Defining heritage within a legal frame causes difficulties because this means that heritage which is not the subject of law, or which is not protected by law, is not heritage. In this way, global, local, ethnical and national heritages and certain types of knowledge can be excluded from the frame of heritage (Carman 2002: 16).

National governments are describing archaeological heritage in a variety of ways, with the emphasis placed on various antiquities, which have sites, monuments and resources of national meaning older than 100 years. English Heritage, for example, has its own criteria for describing monuments of national importance. These criteria exclude the early prehistoric locations, visible only on the surface. Consequently only the most spectacular remains, such as tombs, roman villas and medieval castles etc, are presented to tourists and the public. The associations of archaeologists on the other hand are also describing archaeological heritage in their own way. The Institute of Field Archaeology describes archaeological heritage as material remains of human activities and as a resource that is vulnerable and finite. The Institute for the Protection of Heritage ${ }^{1}$ (ZVKDS) additionally describes as archaeological heritage, archaeological sites, objects and all remains and objects and all human traces from a previous era whose conservation and research contribute towards the revealing of the historical development of humankind and its relation with the natural environment.

Changes are happening slowly. English Heritage, for example, is also now documenting the non representative remains of human activities. Skeates suggests stopping using the adjective 'archaeological' when speaking about heritage, as the meanings of monuments and remains of past cultures are not only archaeological. This meaning has been attributed to heritage by archaeologists who are claiming the right to study and control this type of heritage. For local inhabitants and tourists these remains have a cultural and symbolical value (Perko 2010: 158-159).

\section{MODERN MUSEUM}

The museum, as a public service, only appeared between the end of the $17^{\text {th }}$ century and the start of the $18^{\text {th }}$ century (Walsh 1992: 20; Maroević 1993: 28), although we can trace the origins of the museum further into the past, for example in the Ptolemy museum in Alexandria, which contained an enormous collection with a library and was the domain of wise men, philosophers and historians (Vergo 1989: 1; Maroević 1993: 18).

According to Šola (Šola 1985) the traditional museum is disciplinarily specialised and

1 Resource: http://www.zvkds.si/sl/kulturna-dediscinaslovenije/kategorije/2-arheoloske-dediscina/ 
faithful to its roots in the $18^{\text {th }}$ and 19th centuries, when the natural sciences dictated the specialisation. These museums were in fact the declining mechanisms of the society. Modern museums, created in $20^{\text {th }}$ century, are meant for all the public. With increased quality of life comes an increase in the number of people with more free time who need to be attracted into museums. Museum first had to become available, and secondly, more comprehensive (Šola 2003: 189). The information era brought big changes to museum professionalism. That is why we can say that museums attained a double, socially active and in a certain sense even socially constitutive, role, or task, in the information society. The first task is of content nature and relates to the communication of cultural content; the second task is related to the reestablishment of broken social equivalence. The tasks became implicit functions of the modern museum as a centre of certain districts.

The museum today is a place of collective identity, which contributes to the interconnectivity, affirmation and realisation of cultural, national and European identity. The modern museum links the philosophy of ecomuseums (that serve and satisfy the needs of the community), the philosophy of inclusive museums (that are intended for and answer to the needs of different target groups and visitors with special needs, including minorities, and that are therapeutic) and philosophy of interactive museums (where the visitor can vary and interact using communication tools).

\section{THE PRESENTATION OF ARCHAEOLOGICAL HERITAGE INSIDE AND OUTSIDE THE MU- SEUM}

Due to the topic of research, we are more interested in the interpretation apparatus which helps to present archaeological heritage in the museum. As a result of this we will only men- tion the forms of presentation of archaeological heritage outside the museum, mostly because museums often manage immovable archaeological heritage, for example archaeological parks, and also because the interpretation infrastructure outside the museum is similar to that found inside the museum.

Interpretation infrastructure, as explained in the Ename Charter (Pirkovič 2012: 46), covers the devices, equipment or places intended for interpretation and presentation, with the help of new and classical technologies. The interpretation infrastructure are the tools such as the boards, panels, kiosks, showcases, routes (outside of museum) and various signs (indicating the direction of the visit and the notifications on safety). Interpretation infrastructure does not mean only exhibitions, but also web presentations, brochures, posters, guides and other printed/paper material, souvenirs, devices for audio-video guidance, multimedia equipment and programs or games that can be accessed via mobile phones and other ICT devices etc. Virtual reconstruction as a type of multimedia tool makes possible many economical versions and performances of different and parallel solutions. It enables many parallel solutions, while the version in real life has only one. This most often leads to the destruction of the archaeological monument, if it is performed in situ. The advantage of virtual reconstruction is the fact that it enables the visitor to take an active role and offers an interpretation which fits the visitor's wishes. Besides being an economically smarter solution, it is also preferable in cases where it is not possible to preserve either the monument itself or the access to it (Breeze D. and A. Thiel 2005 (in: Perko 2010:206)). It also provides for the inclusion of findings in their primary context, which contributes immensely to the understanding of the way of life of the first inhabitants of the reconstructed space. As a negative consequence we can consider a fact that this type of reconstruction can deter the visitor from visiting the original 
structure in situ. When planning and choosing the museum's interpretation infrastructure we have to consider that individual equipment or devices cannot override the heritage itself or the values of the community which identifies itself with the heritage. It is of great importance which textual, visual, graphical or audiovisual tools we use as part of the infrastructure or as a means of interpretation. Also, the design has to be of good quality and appropriate. One needs to know that for efficient interpretation, it must consider the needs of the visitors and the expectations of the visitor target groups; it should be interactive or offer to the visitors a rich experience, it should effect not only the mind but all the senses as well and it must arouse the imagination (Pirkovič 2012: 45-46). Interpretation tools also comprise individual or guided tours and museum presentations. It is also advised that they include more imaginative forms which leave a stronger impression on the visitors. What we have in mind are demonstrations, workshops, live history (or re-enacting the past) and the organisation of events and activities in which the visitors can take part (for example culinary experiences, taking part in various tasks). The interpretation of cultural heritage, made especially for children and young adults, is sometimes called heritage pedagogics, a pedagogical program or an educational program. These are usually included in school or preschool curricula or in extracurricular school programs. Also very popular are open discussions, meetings and festivals, which are, according to American and English experiences much more successful than teaching in the form of lectures (Jones 1996 (in: Perko 2010: 211)). Re-enacting the past is also a very popular way of presenting monuments and their contents in the West. Many warn, however, that this method carries the risk that the participants may believe what they see is a real image of the past (Perko 2010: 211).

The aforementioned forms of interpretation can take place in the museum or elsewhere, for example in schools, touristic places or in other areas of heritage.

When speaking about presenting immovable archaeological heritage it is obvious that it is important to already have in mind the desired method of presentation while excavating. When such decisions are taken, very often the opinion of archaeology as a science and the demands of the conservation discipline do not match. At the same time the solutions that science suggests do not match those the local inhabitants want and expect. That is why, when searching for a good solution, the principle was established of considering certain archaeological sites from the integrated perspective of the protection of archaeological heritage, this is to say from a wider social perspective which considers its meaning for the local population. Often the heritage presentation measures or procedures of the structure or area are accomplished first, with the possibility for the later development of a programme of interpretation with the use of interpretive tools. The purpose of the presentation is, of course, presenting heritage to the public and the preservation, consolidation and revival of heritage. Let us consider some forms of the presentation of (immovable) archaeological heritage: anastylosis, archaeological reconstruction, and archaeological presentation. Anastylosis is a type of reconstruction and is mostly used in presenting archaeological remains as well as in some other cases. It comprises the actual assembly of parts of the monuments that were distributed in various locations and rediscovered while excavating. Archaeological reconstruction is used only to present archaeological remains. This method cannot be performed at the original location and cannot be accomplished using the original structures and materials. According to the recommendations of the Venice Convention of 1966, archaeological monuments are not to be built on or presented as a whole, unless the evidence for such actions is supported with archaeological documentation. The goal is a trustworthy interpretation with a 
high degree of authenticity and not a hypothetical interpretation with a low degree of authenticity. At the same time the remains need to be protected before further deterioration, the safety of the visitor has to be provided for, care needs to be taken with the management of the remains and the monument needs to reclaim its original function from any changes or reconstruction (Perko 2010: 204). Archaeological reconstruction can also be based on the method of experimental archaeology. This is a method of archaeological interpretation which uses or recreates partial or total views of past societies, with the use of new materials and historical techniques. Archaeological presentation is used, for example, in presenting the built or (very rarely) painted heritage. It is typical for this method to show, on the walls of the building, all phases of the building's history. Today it is used only to a limited extent, as a presentation of this type is not easily comprehensible for the public. When the method of presentation is related to the management of the heritage, we talk about the following forms of presentation and interpretation of heritage: open museum, archaeological park, ecomuseum, interpretation centre, cultural route and presentation on special occasions (Pirkovič 2012: 43-44).

The most successful turned out to be those interpretations of archaeological monuments that managed to embrace them as whole, even if in a simple or even low cost way. From the museological point of view, a successful musealisation of an archaeological site is one where the archaeological findings or the site itself are turned into the supporters of complex ideas originating in the cultural contexts of the primary environment (Maroević 1986 (In: Perko 2010: 206)).

\section{MUSEOLOGY VERSUS ARCHAEOLOGY}

The subjects of research in museology are the goals and politics of museum operation and its educational, political and social role. It also studies the documentation and communication views of museum operation and various groups of visitors and non visitors. Museology carries interdisciplinarity in its nature, as it draws from sociological sciences (identity, needs of society), educational sciences (knowledge of development, learning and education) and from heritage sciences (preservation). Museology is, thus, interested in the social context of heritage, what heritage means in the society and where its place is in society. It argues for the inclusive and unifying power of heritage. It also deals with problematic heritage, for example in areas of conflict or where heritage has a background of conflict (heritage of world war, heritage in war zones, heritage of colonised people etc). Museology in itself is a relatively new discipline. At the time of the opening of the first museums nobody thought they were a phenomenon worth investigating. In fact, the recognition of museums and/or museology as an independent discipline with its own area of research only happened recently (Vergo 1989: 1-3).

Observing both disciplines from a distance, we can notice that they share heritage as the same object of research even though, at first glance, this appears to divide them. Archaeology (according to Carman) does not produce heritage, only archaeological resources. So, heritage is something that is for the public. If we expand this thought, heritage is, therefore, produced by museums, by the changing status of archaeological artefacts in the process of musealisation. When the object becomes musealia, it becomes a monument, and thus, heritage. Museums in this sense are recognising the heritage and they manage it, as well as interpret it, for the public. On the other hand, archaeology as a science explores the heritage, 
documents it, partially conserves it and scientifically interprets it.

As a branch or sub discipline of archaeological science, with the task of enabling communication between science and the public, and with special concern for ethics and public finances, the so called public archaeology was born. Its theoretical and practical knowledge derives from conservation, restoration and museological sciences. Archaeology for public is a way of studying, interpreting and managing archaeological sites (and findings) in cooperation with the local community. It enables the communication of the cultural content of monuments in a wider contemporary historical-political and cultural discourse of everyday life, in the frame of an existing, social historical environment and according to the psychophysical needs of the visitors (Merriman 2004).

The start, or birth, of public archaeology can be seen in the recent years in Slovenia, mostly with rare presentations of the findings of established excavations (by organised visits and temporary exhibitions) and by its inclusion into university curricula.

We can expect that the enforcement of museology and public archaeology in academic circles will make archaeology more accessible, open and "people friendly".

Archaeology as a science and heritage are, at best in, crisis and definitely in a very uncertain situation, reflecting the crisis of the system and society. In a time when the state budget for culture (and with this for heritage too) is diminishing, its focus seems too narrow and too much on the side of the natural sciences, and not enough on society.

\section{CONCLUSIONS}

In the first two parts of this essay we wanted to point out the two different ways to look at and to understand archaeology. When looking at the wide range of literature on archaeology, the reader most often understands from the context when the writing is about archaeology as a science and when it is about heritage. By dividing and defining both terms, we wanted to show that precise terminology is necessary and appreciated. The theoretical archaeologists (Shanks, Welsh) have, in the last two decades, also started to write about heritage. However, their attitude towards it is mostly negative ("product of postmodernist past", "supermarket"), although sometimes they contribute to it a positive meaning ("carrier of identity"). Furthermore, we were interested in the presentation and the forms of presentation of archaeological heritage in the museum. For this reason we started from the perspective of how the modern museum should look in comparison with the traditional museum. In this way we can truly understand the changed philosophy of museum operation and also the importance of a "custom made" and appealing interpretation that is made with, and for the people. The final, and most important, conclusion concerns the question of openness. It is very important for archaeology (in Slovenia) to become more open. This can be accomplished through the adoption and adaptation of the museological principles of interdisciplinarity and social inclusion, accessibility, participation and representation. These are the principles of sustainable development and the way towards empowering the meaning of archaeology in society. Museology represents the possibility of connecting heritage institutions (museums...) with other initiatives in the field of heritage. Hence, museology offers the model for integrating archaeology, both as science and as heritage, into the community. 


\section{BIBLIOGRAPHY}

Bapty, I. And Yates, T. (ed.) 1990

Archaeology after structuralism. Post-structuralism and the Practice of Archaeology, London: Routledge.

\section{Bennett, T. 1995}

The Birt of the Museum: history, theory, politics. London and New York: Routledge

\section{Carman, J. 2002}

Archaeology and Heritage. An Introduction. London and New York:Continuum.

\section{Peniston, W.A (ed.).1999}

The New Museum: Selected Writings by John Cotton Dana, Washington DC: American Association of Museums.

\section{Gardin, J.P. 1989}

The role of local knowledge in archaeological interpretation, in: Archaeological approaches to cultural identity, ed. S. Shennan, London and Boston: Unwin Hyman, 100-110.

\section{Hodder, I. and Preucel. R. 1996}

Contemporary Archaeology in Theory: A Reader, Cambridge: Cambridge University Press.

\section{Hodder, I. et al. 1995}

Interpreting Archaeology. Finding meaning in the past, London and New York: Routledge.

\section{Hodder, I. 1993}

Changing configurations: The relationships between theory and practice, in: Archaeological resource management in the UK. An Introduction. Hunter, J. and Ralston, I. eds., Stroud: Alan Sutton Publishing Ltd.

\section{Hodder, I. 1992}

Theory and Practice in Archaeology, London: Routledge.

\section{Hodder, I. 1986}

Reading the Past: Current approaches to Interpretation in Archaeology, Cambridge: Cambridge University Press.

\section{Hooper-Greenhill, E. 1999}

Museum, media, message, London and New York. Routledge.

\section{Hudson, K. 1987}

Museums of Influence, Cambridge: Cambridge University Press.

\section{Mensch van, L. and Mensch van P. 2011}

New trends in Museology. Celje: Muzej novejše zgodovine.

\section{Merriman, N. 2004}

Public Archaeology, London: Routledge.

\section{Novaković, P. 2003}

Osvajanje prostora. Razvoj prostorske in krajinske arheologije. Ljubljana: Filozofska fakulteta.

Olsen, B. 2002

Od predmeta do teksta. Teorijske perspektive arheoloških istraživanja. Beograd: Geopoetika.

\section{Perko, V. 2010}

Muzeologija in arheologija za javnost - Muzej Krasa. Doktorsko delo. Univerza u Zagrebu.

\section{Pirkovič, J. 2012}

Arheološko konservatorstvo in varstvo nepremične kulturne dediščine. [e-book], Ljubljana : Znanstvena založba Filozofske fakultete. Available through Department of Archaeology in Ljubljana Library: http://arheologija.ff.uni-lj.si/studij/gradivo/koservatorstvo/ArheologijaZaJavnosti.pdf 
Renfrew, C. and Bahn, P. G. 1991

Archaeology: Theories, Methods, and Practice.

London: Thames and Hudson Ltd.

Shanks, M. and Tilley, C. Y. 1992

Presenting the past: towards a redemptive aesthetic for the museum, in: Re-Constructing Archaeology. Theory and Practice. London and New York: Routledge. 68- 97.

Skeates, R. 2000

Debating the Archaeological Heritage. London: Duckworth.

Šola, T. 2003

Eseji o muzejima i njihovoj teoriji : prema kibernetičkom muzeju, Zagreb: Hrvatski nacionalni komitet ICOM.

\section{Šola, T. 1985}

Prema totalnom muzeju: disertacija. Filozofska fakulteta, Univerza v Ljubljani.

Tilley, C. (ed.) 1993

Interpretive Archaeology, Oxford: Berg.

\section{Vergo, P. 1989}

The New Museology. London: Reaktion Books Ltd.

\section{Walsh, K. 1992}

The Representation of the Past: Museums and Heritage in the Post-Modern World. London and New York: Routledge.

\section{REZIME \\ ARHEOLOGIJA U OČIMA \\ MUZEOLOGIJE \\ - ARHEOLOGIJA KAO NAUKA I KAO NASLEĐE -}

\section{KLJUČNE REČI: ARHEOLOŠKO NASLEĐE, INTERPRETACIJA, PREZENTACIJA, MODERNI MUZEJ, MUZEOLOGIJA.}

Izvesno je da se arheologija tokom poslednjih decenija znatno izmenila i više nije ograničena samo na istraživanja, već daje podatke i predstavlja ispomoć za neobnovljive izvore, tj. naše nasleđe. Promene su, kao takve, donele sa sobom novu vrstu odgovornosti, kroz koju se od arheologije očekuje ne samo da pokaže izbalansiranu i pouzdanu interpretaciju prošlosti, u smislu da ne prikazuje prošlost kao događaj izolovan od savremenog sveta, već kao potku za savremeni svet. Zapitali smo se koja je razlika između arheologije kao nauke i arheologije kao nasleđa, kako su se ovi koncepti razvijali, u kojim su kontekstima korišćeni, a naročito šta arheologija kao nauka može da dobije od heritologije i muzeoloških ideja. U potrazi za odgovorima, koristili smo iscrpnu literaturu iz oblasti teorije arheologije, heritologije i muzeologije. Zaključci proizilaze iz poređenja tri napred navedena koncepta. 